\title{
Challenges in the implementation of the City of Johannesburg's Expanded Social Package in alleviating COVID-19 induced food insecurity
}

\begin{tabular}{|c|c|}
\hline \multicolumn{2}{|c|}{ 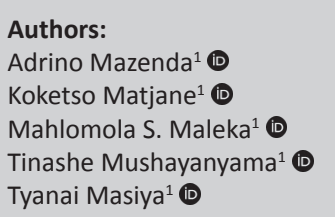 } \\
\hline \multicolumn{2}{|c|}{$\begin{array}{l}\text { Affiliations: } \\
{ }^{1} \text { School of Public } \\
\text { Management and } \\
\text { Administration, Faculty of } \\
\text { Economic and Management } \\
\text { Sciences, University of } \\
\text { Pretoria, Pretoria, } \\
\text { South Africa }\end{array}$} \\
\hline \multicolumn{2}{|c|}{$\begin{array}{l}\text { Corresponding author: } \\
\text { Adrino Mazenda, } \\
\text { adrino.mazenda@up.ac.za }\end{array}$} \\
\hline \multicolumn{2}{|c|}{$\begin{array}{l}\text { Dates: } \\
\text { Received: } 01 \text { July } 2020 \\
\text { Accepted: } 26 \text { Feb. } 2021 \\
\text { Published: } 30 \text { Apr. } 2021\end{array}$} \\
\hline \multicolumn{2}{|c|}{$\begin{array}{l}\text { How to cite this article: } \\
\text { Mazenda, A., Matjane, K., } \\
\text { Maleka, M.S., Mushayanyama } \\
\text { T. \& Masiya, T., 2021, } \\
\text { 'Challenges in the } \\
\text { implementation of the City of } \\
\text { Johannesburg's Expanded } \\
\text { Social Package in alleviating } \\
\text { cOVID-19 induced food } \\
\text { insecurity', Africa's Public } \\
\text { Service Delivery and } \\
\text { Performance Review 9(1), } \\
\text { a470. https://doi.org/ } \\
\text { 10.4102/apsdpr.v9i1.470 }\end{array}$} \\
\hline \multicolumn{2}{|c|}{$\begin{array}{l}\text { Copyright: } \\
\text { ( 2021. The Authors. } \\
\text { Licensee: AOSIS. This wo } \\
\text { is licensed under the } \\
\text { Creative Commons } \\
\text { Attribution License. }\end{array}$} \\
\hline \multicolumn{2}{|l|}{ Read online: } \\
\hline 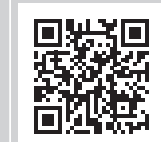 & $\begin{array}{l}\text { Scan this QR } \\
\text { code with your } \\
\text { Smart phone or } \\
\text { mobile device } \\
\text { to read online. }\end{array}$ \\
\hline
\end{tabular}

Authors:

Mahlomola S. Maleka ${ }^{1}$

Tinashe Mushayanyama ${ }^{1}$ (D

Tyanai Masiya ${ }^{1}$ (D)

Affiliations:

chool of Public

Administration, Faculty of

Economic and Management

Corresponding author:

Adrino Mazenda,

Dates:

Accepted: 26 Feb. 2021

How to cite this article: Mazenda, A., Matjane, K,

T. \& Masiya, T., 2021

'Challenges in the

Social Package in alleviating

COVID-19 induced food

Performance Review 9(1)

a470. https://doi.org/

Copyright:

Licensee: AOSIS. This work

is licensed under the

Creative Commons

Attribution License.
Background: The coronavirus disease 2019 (COVID-19) pandemic has subjected the African urban population into abject poverty. Local government initiatives, such as the City of Johannesburg's (CoJ) Expanded Social Package (ESP) 'Siyasizana' [we help each other], have been established to enhance food security amongst the city's most vulnerable based on their level of income.

Aim: This article analysed the extent to which the ESP was effective in addressing food insecurity in the wake of COVID-19.

Setting: This research was descriptive and explanatory in nature that played an important role in obtaining an in-depth interpretation of the challenges of the implementation of ESP in mitigating food insecurity in the CoJ.

Methods: This article utilised a qualitative case study design with the aid of existing literature, municipal documents and authoritative internet sources in order to analyse the extent to which the ESP is effective in addressing food insecurity in the wake of COVID-19.

Results: This article found out that the ESP did not expressly address the COVID-19-induced food insecurity because of numerous challenges, namely awareness, stigmatisation, qualification and hidden costs.

Conclusion: The CoJ should bring in private players to finance the programme as COVID-19 has increased the number of beneficiaries, relax the requirement for in-person application to allow for online registration, increase the ESP poverty threshold of R6100 to cater for those on the border of poverty and diversify its means testing to include other criteria such as Unemployment Insurance Fund (UIF), which will provide much needed relief to those who might have lost income.

Keywords: food insecurity; expanded social package; City of Johannesburg; South Africa; COVID-19; unemployment insurance; poverty threshold.

\section{Introduction}

The coronavirus disease 2019 (COVID-19) outbreak is not only a health crisis but also a socioeconomic crisis, which has impacted all countries' economic sectors. In the South African context, the pandemic has left all the sectors constrained.

Consequently, the pandemic has worsened poverty and inequality amongst the population. The South African government introduced various initiatives, such as the Economic Relief package, to alleviate abject poverty and sustain the population for the initial 6 months of the lockdown, anticipating the opening up of the economy and/or possible discovery of a vaccine. Numerous complaints are levelled against the Economic Relief Fund (ERF), especially issues on disbursement. Various initiatives from the South African municipalities and non-governmental organisations (NGOs) were necessary to cushion the population from severe food insecurities and abject poverty, arising from the COVID-19 effects. Champion to these initiatives is the City of Johannesburg (CoJ) Expanded Social Package (ESP) 'Siyasizana', established in 2008, to provide free basic services to the poor and enhance food security amongst the city's most vulnerable based on their level of income. Key in this programme is strategies such as the provision of free basic water and electricity; the food bank targeted at the indigent families to receive free vegetables regularly, and other food resilience initiatives; utility subsidies and exemptions; skills development; social service interventions; youth programmes; and intervention programmes for the homeless 
(Socio-Economic Rights Institute of South Africa [SERI] 2018:22). In response to COVID-19, the city reviewed its rates, rebates and municipal service charges as part of the ESP programme to mitigate the impact of the coronavirus on ratepayers. Consequently, the city reviewed the ESP programme's current terms and conditions, which require policy adjustments, with the aim of broadening the net for distressed ratepayers (Cox 2020).

Citing these interventions coupled with the continuous deterioration of the South African economy, evidenced by the closure of businesses and informal unemployment in which most of the city's vulnerable work, this article seeks to investigate the extent to which the ESP strategy is effective in addressing food security challenges that citizens face. Consequently, this article delves into challenges that the city faces in implementing the ESP, amidst the COVID-19 pandemic, and the possible recommendations to ensure effectiveness in the implementation of the programme in the city, without hampering the city's budget.

This article utilises a qualitative case study design with the aid of existing literature, municipal documents and authoritative internet sources in order to analyse the extent to which the ESP is effective in addressing food insecurity in the wake of COVID-19.

This article is structured as follows: After the introduction and methodology, a brief review of literature is provided. Following is the overview of the CoJ ESP; the relationship between the ESP, food security and poverty; the regulatory framework governing food security and poverty; and results and discussion on challenges that the city faces in implementing the programmes, prior to COVID-19 and during the COVID-19 pandemic, citing adjustments, most of which were not initially budgeted for. Finally, recommendation and conclusions on how to improve the programme implementation in meeting the COVID-19induced socio-economic challenges that citizens face, in particular poverty, whilst avoiding a strain on the city's resources are also provided.

\section{Methodology}

This article used the qualitative research approach that enabled the researchers to have a more comprehensive understanding of the extent to which the ESP is effective in addressing food insecurity in the wake of COVID-19. As observed by Babbie and Mouton (2012:270), qualitative studies enable a broad description and understanding of phenomenon rather than merely explaining it. The approach assisted in the analysis of the extent to which the ESP is effective in addressing food insecurity in the wake of COVID-19. Embedded in the qualitative approach is the case study design, which examines real-life events through a detailed conceptual examination of incidents and their interaction. Case studies permit discrepancies in functional, intrinsic and collaborative methods to be used in data analysis (Miles \& Huberman 1994:7-15). Through the use of secondary sources and documents, the qualitative research approach tends to focus on how people or groups view social reality differently (Kumar 2011), which made it more relevant to this study. Through the analysis of secondary sources, the researcher is able collect sufficient knowledge from a number of sources without compromising on data quality, costs and coverage (Doolan \& Froelicher 2009:13). Key secondary sources used include the CoJ Social Economic Package, the Integrated Development Plan (IDP) and various reports, journal articles and online articles providing insight into how to address the COVID-19-induced food insecurity and poverty in the CoJ through the ESP. The key secondary sources are presented in Table 1.

Internet sources considered as credible were those written by authoritative writers or institutions. The neutrality of the information source was also used as a criterion of identifying truthful and credible data. The broad spectrum of secondary sources provided rich and diverse sources of data, which provided a comprehensive understanding and interpretation of the extent to which the ESP is effective in addressing food insecurity in the wake of COVID-19.

The data gathered from secondary sources were analysed using a thematic analysis. A thematic analysis approach involves identifying themes and patterns in the data (Wagner et al. 2012).

Similarly, Braun and Clarke (2006) argued that thematic analysis minimally organises and describes your data set in detail and also often goes further than this, and interprets various aspects of the research topic'. Hence, the collected data were categorised, synthesised and coded to identify themes. Data presentation was then presented using the identified themes.

\section{Literature review}

In countries that are affected by COVID-19, debate is taking place in an environment of high scientific uncertainty, and questions of science, medicine, public health and public policy need vigorous academic debate (Prasad \& Jeffrey 2020). In view of the fact that we do not seem to have enough information on the prevalence of COVID-19 and the consequences of the infection on a population; academics,

\begin{tabular}{|c|c|c|c|}
\hline $\begin{array}{l}\text { Academic } \\
\text { sources }\end{array}$ & CoJ sources & Research institutions & Legislation \\
\hline $\begin{array}{l}\text { WOS } \\
\text { accredited } \\
\text { journals }\end{array}$ & $\begin{array}{l}\text { City of Johannesburg } \\
\text { (CoJ) Expanded Social } \\
\text { Package (ESP) } 2008\end{array}$ & $\begin{array}{l}\text { Socio-Economic Rights } \\
\text { Institute of South Africa } \\
\text { (SERI) } 2018\end{array}$ & $\begin{array}{l}\text { Constitution of } \\
\text { the Republic of } \\
\text { South Africa } 1996\end{array}$ \\
\hline $\begin{array}{l}\text { Scopus } \\
\text { accredited } \\
\text { journals }\end{array}$ & $\begin{array}{l}\text { CoJ growth and } \\
\text { development } \\
\text { strategy } 2019\end{array}$ & - & $\begin{array}{l}\text { Skills Development } \\
\text { Act } 1998\end{array}$ \\
\hline $\begin{array}{l}\text { DHET } \\
\text { journals }\end{array}$ & CoJ IDP [2019]2020 & - & $\begin{array}{l}\text { National } \\
\text { Development Plan }\end{array}$ \\
\hline
\end{tabular}

Note: Please see the full reference list of the article, Mazenda, A., Matjane, K., Maleka, M.S. Mushayanyama, T. \& Masiya, T., 2021, 'Challenges in the implementation of the City of Johannesburg's Expanded Social Package in alleviating COVID-19 induced food insecurity', Africa's Public Service Delivery and Performance Review 9(1), a470. https://doi.org/10.4102/ apsdpr.v9i1.470, for more information

WOS, World of Science; DHET, Department of Higher Education and Training; IDP, Integrated Development Plan. 
scientists and practitioners have attempted to answer fundamental, vital and unprecedented questions. How fast does the virus spread if left unabated? How lethal is it? What can societies do to slow it? What happens when we selectively evolve and relax our public health interventions? Should governments centrally control prevention and control measures? In what ways can different sectors of society contribute to prevention and control? What are the socioeconomic consequences of the pandemic's control and prevention measures?

According to Weible et al. (2020:228), proponents of crisis management point out that crises of this nature 'bring crucial leadership challenges associated with decision making, public information, sense making, accountability, learning, and reform and but also require broad collaboration and coordination involving multiple individuals and organisations'. Ping, Cui and Pan (2011) revealed that there is not much that is known regarding how distinct natures of crises determine different external environment and consequently result in different organisational strategies to respond. It is not disputed, however, that the government plays an important role in crisis management. But government has to be effective in developing effective policies and promoting effective social support, interactions of individuals, groups, coalitions and networks.

Subsequently, a multiplicity of policy and medical perspectives on the COVID-19 pandemic have resulted in governments and their lower structures such as provinces and local governments taking different measures to deal with both the health and economic impact of the pandemic. Authorities such as Walker et al. (2020), Werner, Stein and De Bonis (2020), Bolongaro (2020) and Kyodo (2020) all point to an array of prevention and control measures taken by some of the most affected countries of the world such as China, the United States of America, the United Kingdom, Japan and South Korea. Notable measures identified to deal with COVID-19 around the world have seen shifts from partial closures to strict lockdowns in countries such as the United Kingdom; promulgation of social welfare safety nets and stimulus packages in countries that include the United States of America, Canada, Japan and South Africa; widespread testing in countries such as South Korea; and China's strict quarantining. Countries such as Sweden and Tanzania's responses have avoided many of the lockdowns of other countries. Adopted prevention and control measures seem to have been influenced by 'contextual factors, including institutional (e.g. constitutional and legalistic structures) factors, cultural orientations, economies and political styles (amongst others)' (Weible et al. 2020:227).

In his seminal work, Woodward (1958) argued that governments are open systems that need careful management to satisfy and balance internal needs and to adapt to environmental circumstances. Therefore, the suitable management strategy is subject to the kind of task or environment one is dealing with. Different strategies need to be considered in different types of environments. Because of lack of enough information on the prevalence of COVID-19 and its consequences in both the health and economic spheres, this makes it extremely complex and full of uncertainty. In order to succeed, governments need to consider both the environmental situations and internal conditions of their countries.

The impact of COVID-19 has led to increased unemployment, poverty and inequality. The shutdown of all economic activities has worsened the already present economic crisis and misery for the poor, with massive job losses and rising food insecurity and poverty.

\section{The City of Johannesburg Expanded Social Package}

The ESP is a basket of benefits which the CoJ allocates to its poor individuals and the households in which they live, based on the level of poverty. The ESP was introduced in 2008 to enhance and expand the core logic of the existing special cases policy for municipal service subsidies (more generally known as the indigent or social package policy) but combines it with a single-window approach to social assistance delivery and critically - alters the targeting mechanism from a householdbased means test to an individually tied poverty index (CoJ 2008). It is in this context that it supports socio-economic life of communities that have been affected by COVID-19. The programme is offered by the Social Development Department and has been designed to help disadvantaged households living on a monthly income of not more than R6086.37 (\$352.48) to gain access to metered water, electricity and nonmetered services - refuse removal and property rebates based on their level of poverty (Gazette 2020).

Key to the ESP is initiatives targeted at non-municipal account holders (backyard dwellers, inner city apartment dwellers and tenants). These initiatives include household and individual services (power and utility subsidies and exemptions), skills development, social service interventions, food resilience, youth programmes and intervention programmes for the homeless that would enable beneficiaries to exit the social assist programme (SERI 2018:22).

\section{The Expanded Social Package qualifying criteria}

According to the ESP policy, to register for the services provided by the social package, individuals should provide the following documents: South African identity document (ID), 3-months' bank statements indicating proof of payment or a South African Social Security Agency (SASSA) card, CoJ rates and taxes, city power account number, $\mathrm{CoJ}$ water account number, and Eskom account number or prepaid account number (Fourie 2018).

The selection of qualifying individuals is based on their:

- level of poverty, benchmarked by the following individual factors: current income, beneficiaries to pension, child 
support, disability, social relief of distress and/or unemployment grant

- total number of household dependents and number of dependents of school age (weighing $70 \%$ of the poverty index score, determined by the $\mathrm{CoJ}$ )

- ward and small area factors (i.e. number of primary schools, number of high schools, number of clinics, number of hospitals, number of police stations, number of taxi routes, number of bus routes, number of train stations, reported number of violent crimes per 1000 residents in previous quarter, reported number of total crimes per 1000 residents in previous quarter, number of local IDP projects in the targeting area)

- percentage of paved roads

- availability of free rudimentary service level 3 (LOS-3) water

- availability of electricity

- the rank of the ward from 1 to 109 in terms of the weighted index of the above factors

- the weighing $30 \%$ of the poverty index score.

The score received by an individual will determine their eligibility and the band of assistance (CoJ 2008:9).

\section{The Expanded Social Package institution arrangements}

The city's social workers are tasked with gathering information on the needs and living conditions of individuals from their applications. Two social workers are placed in each administrative region to provide assessment and verification capacity. The group of social workers are further tasked with gathering and capturing applications they received and decisions they took as a collective to refine and guide future decision-making and the decisions concerning the special needs of water mechanism (CoJ 2008:21).

\section{The Expanded Social Package operation}

The initial application process is initiated by the CoJ Customer Service Centre in each administrative region.

In each region are co-located service delivery points for the Department of Home Affairs and the SASSA. At the point of application, the applicant citizen must show his or her ID number. In the event that he or she wants to be eligible for benefits provided directly to a property (water, electricity, taxes and sanitation), an address must be registered for this reason using a utility bill or prepaid metre token, along with the names and identification numbers of each person living there. This address will be used to calculate the ward and small area variables in the individual's poverty index score.

Poverty score calculation is automated through a dataintegration system application, previously mentioned in the qualifying criteria. Subsidies are then added to the household on an additive-by-person basis, up to a maximum limit per assistance unit. For example, a household of five individuals, with at least three qualifying for Band 1 assistance, will receive $5 \mathrm{~L} \times 50 \mathrm{~L}$ per person per day or $250 \mathrm{~L}$ per day of water subsidies, up to a limit of $15 \mathrm{~kL}$ per month. Any additional water on the basis of specific special needs would have to be approved as part of the special needs water appeal process. The declaration of residence in a household will be documented as an appended record of the relevant ID number and it will be the only property for which the person bearing that ID number may claim a subsidy. In the case of any disagreement as to the residence of a specific individual, that individual's declaration in person at his or her regional customer service centre shall take precedence over any declaration made by another individual residing in the household of the reporting person.

Only those qualifying for any of the social package assistance bands will have preferential access to the Job Pathways applicant pool and related initiatives intended to provide an exit route from social assistance.

In addition, all currently qualified users of the social package will be registered in a database, updated regularly, from which all of the skills development and job creation initiatives produced by the city will obtain at least $75 \%$ of their intake (CoJ 2008:8-14).

Any CoJ department designing a measure or initiative designed to benefit the poor must use this database as the source of their programme participants. It is intended to consistently ensure that households eligible for social assistance are subject to the full range of interventions provided by (or in partnership with) the $\mathrm{CoJ}$ in compliance with the CoJ Growth and Development Strategy Priority of Pro-Active Absorption of the Poor (CoJ GDS, PPAP). A one-window access platform for financial services given to people with special needs would be paired with the existing ESP service subsidies. The categorisation is based on the following: human immunodeficiency virus (HIV) status; risk of terminal disease, disability, advanced age, very low basic skills and residency in one of the following: child-bearing household, elderly household and single parent household; history of sexual or physical abuse and history of drug abuse; ex-combatant status and previous imprisonment or history of criminal activity (CoJ 2008; Ebrahim \& Makarela 2018).

The Human Development Manager of each region will maintain an updated list of programmes serving these groups, including details of a dedicated contact person and eligibility criteria. Inclusion in such a list is a prerequisite of receipt of social support for the present and future financial cycles.

An on-site social worker conducts case interviews with individuals, ascertains the appropriate programme placement and makes plans for placement before clients exit the customer service centre. The social worker is mandated to issue additional free basic water vouchers to HIV and chronic illness applicants (CoJ 2008; Ebrahim \& Makarela 2018). 


\section{Regulatory framework governing food security}

Section 27 (1) of the Constitution of the Republic of South Africa (1996) stipulates that everyone has the right to adequate food and water. Section 27 (2) further states that it remains the responsibility of the state to ensure that measures that would lead to the realisation of this right are put in place.

In the bid to achieve the above-mentioned objectives the following policies have been aligned with the constitutions mandate. These include the Skills Development Act (1998), whose purpose is to develop the skills of the South African workforce, thereby enhancing their prospects of employment, which could then improve their lives. The ESP has highlighted skills development and youth development programme referrals as one of the benefits of being registered for the programme.

In addition, the National Development Plan has the objective of dismantling the nation's triple threat challenge of poverty, unemployment and inequality through food security by 2030. Plans to achieve this objective include expanding the use of irrigation, security of land tenure and prioritising education on nutrition (Department of Agriculture, Forestry \& Fisheries [DAFF] 2013:5).

Moreover, drawing from the success of Brazil's food security programme, the Department of Agriculture, Forestry and Fisheries established the Zero Hunger Programme. The programme is centred on enhancing the food production efforts of households and poorly resourced farmers, whilst ensuring that individuals have access to essential nutrients (Parliamentary Monitoring Group 2012).

Finally, the National Policy on Food and Nutrition Security, which was introduced in 2013, serves as a framework for achieving the constitutional mandate of providing adequate food and water for all. This policy also serves to guide the three spheres of government in their pursuit of food security. This is performed through the following strategies (DAFF 2013), which are found to be key to achieving food security:

\begin{abstract}
Increased and better targeted public spending in social programmes that impact food security; Efforts to increase food production and distribution, including increased access to production inputs for the emerging agricultural sector; leveraging government food procurement to support community-based food production initiatives and smallholders and the strategic use of market interventions and trade measures which will promote food security. (pp. 5-6)
\end{abstract}

\section{The Expanded Social Package, poverty and food security}

Poverty alleviation, also referred to as poverty reduction, is a series of economic and humanitarian initiatives by government and NGOs to enhance food security (Maphanga \& Mazenda 2019).
The ESP livelihood support initiatives are examples of poverty alleviation strategies for sustainable food security. According to the Food and Agriculture Organization (FAO) (1996), food security refers to the position when 'all people, at all-time have physical and economic access to sufficient, safe and nutritious food that meets their dietary needs and preferences for an active and healthy life'. Four components are drawn from the definition of food security, namely, availability, access, utilisation and stability.

Food availability refers to a state when food can be found in a country and/or area by means of domestically producing the food, commercial imports and/or food assistance from other nations. The element of food availability is achieved through the CoJ Food Resilience Unit. The Food Resilience Unit is an organ of $\mathrm{CoJ}$ meant to empower community members to grow sustainable communal gardens and sell the produce to the Joburg market (CoJ IDP [2019]2020:65). Through the water rebates from the ESP, residents could grow their communal gardens in the fight against COVID-19-induced poverty and hence increase food availability.

Food access refers to a state when an individual(s) has sufficient means to obtain food through food production, purchase or food aid (Gross, Pfeifer \& Preuss 2000:5). It is important to observe that despite a country having tons of food at its disposal, it does not have immediate food accessibility. Food access is influenced by three elements: physical, financial and socio-cultural access. Physical access is concerned with whether or not food is available in areas that individuals have access to. Economic access draws much emphasis on the financial means of individuals. Focus here is on whether or not individuals have the financial means to regularly acquire sufficient amounts of food that would meet their dietary needs. Sociocultural access, the last element, looks at whether food access can be constrained as a result of social ills, which come in the form of discrimination or social conflicts (Simone 2018:19-25). The ESP beneficiaries are prioritised in the job pool as employment opportunities are reserved for at least $75 \%$ of those who appear on the indigent register. This provides these individuals with a greater chance of meeting the access and utilisation element of food security. If an individual is selected for a pathway programme in the ESP, they would not only be trained, but also be compensated for the duration of their training. The South African Cities Network (SACN) ([2018]2019:33) report provides that for the [2018]2019 financial year, the CoJ had an average wage rate of about R200. Access to these funds would not only give beneficiaries an increased income but also a diversification in their dietary needs. Amidst the COVID-19 pandemic, this component is not fully utilised as the lockdown restrictions have made it difficult to access any work opportunities or consequently use of acquired skills for informal income-generating businesses.

The food utilisation element is not only concerned with individuals being able to acquire food but also that the food they acquire is safe and is able to meet their dietary needs 
(Gross et al. 2000:5). The link between the ESP programme and the city's food bank ensures that beneficiaries who are unable to provide for themselves have access to free vegetables on a regular basis, ensuring that they meet their dietary needs (Gazette 2020). Food utilisation is an important component of food security, yet by drawing a distinction between the homeless and the rest of the population, while most of the population is in abject poverty because of COVID-19, the CoJ fails to address the food insecurity issues of the citizens. Consequently, lack of nutritional adequacy arising from eating only vegetables from the food bank is a major concern.

The food stability argument entails that the first three elements of food security (availability, access and utilisation) should not only be considered at a single point in time but also be considered at all times (Gross et al. 2000:5). Through the ESP initiatives of utility subsidies and exemptions, skills development, social service interventions and youth programmes amidst COVID-19, food stability is guaranteed. The initiatives strive with the opening up of the economy for any meaningful contribution to food access and consequently stability.

\section{Results and discussion}

This section discusses the challenges in the implementation of the ESP to both the municipality and the citizens. It is imperative to note that the ESP began in 2008 and has only adjusted some policy issues to beneficiaries for 9 months, since April 2020, in order to respond to numerous COVID19-induced food insecurity and poverty challenges. Most challenges of the programme existed prior to the COVID-19 pandemic; hence, an attempt is made to relate the two time periods. Key to the thematic discussion is the following challenges: the shift from a universal approach to a narrow target approach, stigma and exclusion of vulnerable communities in the qualifying criteria, lack of awareness, lack of funding and food security and poverty.

\section{The shift from universal approach to a narrow target approach}

The shift from utilising the universal approach of disbursing free basic water (6 kL of water) to a narrow target approach was announced in March 2017. The measure was introduced by the former mayor, Herman Mashaba, in a bid to offer financial relief to the CoJ, saving the city at least R320 million (\$18 435 964) (SERI 2018:9). Whilst this shift was set to carry a certain amount of benefits, particularly financial ones, there are hidden costs associated with this shift, which ultimately undermines the efforts made by the programme.

The Socio-Economic Rights Institute of South Africa (2018:10) observed that the move from a universal to a target approach can be deemed ineffective as the indigent register fails to reflect the realities of all communities in the city. Whilst 650000 households out of 1434856 were considered poor, only 321984 individuals were registered.
In addition, the total number of registered individuals was not exclusive to those seeking household services but instead included those who sought individual services in the form of skills development, youth programme and homeless intervention programmes (SERI 2018:39-40). Moreover, there are high administrative costs that come with the use of a targeting approach.

The ESP provides that beneficiaries need to register every 6 months in reassessing their qualification. With the high levels of unemployment in the city, this approach is costly. The COVID-19-induced unemployment and poverty have partly allowed the city to revert to the universal system for 6 months, as most of the population are in need (Gazette 2020). Adopting either of the systems is made at the expense of either of the parties. Attempts should be made to pool funds from private organisations and individuals in support of the ESP initiatives amidst the COVID-19-induced demand. Consequently, efforts should be made to reconcile the ESP, the Economic Relief Stress Grant and other city programmes such as the Food Resilience Strategy in resource disbursement. Reconciling the programmes will ensure equal benefits amongst the citizens who have all been subjected to the same poverty trap.

\section{Stigma}

The registration process for the ESP can only be carried out in person at one of the identified centres within the boundaries of the metropolitan municipality. The SocioEconomic Rights Institute of South Africa (2018:35) finds that there exists a stigma of having to publicly declare one's inability to provide for themselves and their family. According to SERI, this discourages individuals from registering to benefit from such programmes. Whilst lack of awareness could explain the low turnout of the city's most vulnerable, there exists an element of stigmatisation, which was absent in the previous approach. To some extent, this stigmatisation was raised by the member of the mayoral committee for Health and Social Development who reiterated lack of interest, even after awareness measures were implemented (ESP 2018). Amidst the COVID-19 pandemic, the stigma is attached to the fear of contracting infection whilst accessing the centres, as Gauteng is considered a hotspot region.

\section{Qualifying criteria excluding vulnerable communities}

In order for individuals to benefit from the basket of services provided through the ESP (2018) - particularly the household services - the following criteria need to be met:

$[P]$ roviding proof of income, SASSA card and 3 months latest bank statement of all accounts; in the absence of these, a sworn affidavit must be produced confirming no bank account or any other source of income, identity document, city of Johannesburg rates and taxes account, city power pre-paid electricity account number, conventional account number and Johannesburg water account/pre-paid account number. (n.p.) 
Whilst the ESP is seen as a lifeline for many urban dwellers, its benefits are often limited for informal settlement residents. The reason is that there exists a gap in the delivery of basic services, therefore making it impossible for the programme to subsidise residents. The use of communal standpipes, absence of electricity connection and/or metered services hinders informal settlements' ability to register and gain access to household services, as a result excluding the most vulnerable in the metropolitan (Ebrahim \& Makwarela 2018). The COVID-19 lockdown measures have subjected the urban population to abject poverty. Apart from losing employment, hunger is rife. The ESP appeal to mostly communal regions, neglecting the urban vulnerable dwellers that were made vulnerable by the COVID-19-induced challenges.

\section{Lack of awareness}

A study performed by Mtshali (2018) on the participation of community members around the Diepkloof area found that a lack of awareness contributed immensely to the low registration of ESP within the area. Mtshali (2018) further noticed that there exists a gap with communicating information on the programme as those who were encouraged to register were not in any way briefed by their local councillor or officials on the benefits that come with the programme and the duration that one is entitled to the services; this has then resulted in many not re-registering for the provision of these services despite not having the means to pay for them. With the advent of COVID-19 and a more centred approach on the health awareness campaigns, little has been made to create awareness about the ESP adjustments, and the 6 months' rebate provisions since April 2020, in accommodating a new band of qualifying poor households.

\section{Lack of funding}

The CoJ requires the consideration of the rebate qualification criteria based on a certain threshold income adjusted annually on 01 November. With the poverty-induced unemployment challenges brought about by the COVID-19 pandemic, there has been an increase in beneficiaries to the programme. This constrains the city's resources and ability to deal with other critical service delivery challenges. The government is already incapacitated because of its own challenges and the recent rolling out of the Economic Relief package, targeted also at the poor and beneficiaries to the ESP (Gazette 2020; Webster 2020).

\section{Food insecurity and poverty}

The CoJ ESP does not respond directly to the COVID-19induced food insecurity and poverty challenges. The indigent food banks, offering vegetables to the homeless, do not reflect all the constituencies of a balanced diet or nutrient adequacy. Consequently, other vulnerable groups in society are neglected, like the youth, women and children, most of them who are not beneficiaries of the existing SASSA grants. This, therefore, violates section 27 (1) of the Constitution of the Republic of South Africa (1996), which stipulates that everyone has the right to adequate food and water. Section 27 (2) further states that it remains the responsibility of the state to ensure that measures that would lead to the realisation of this right are put in place. The state role does not spare the municipality either.

\section{Recommendations}

Coronavirus disease 2019 has subjected most of the urban dwellers to abject poverty and hence a need to reclassify beneficiaries to the city's food banks. Moreover, the food banks should offer general nutritional adequacy in diet. The vegetables provided are not adequate for the required balanced diet.

In addition, the city should strive to balance with available resources to avoid a deficit in their balance of payments. Public-private partnership synergies must be fostered to finance the city's commitments. Debt burden has long-term effects of hurting the taxpayer or subsequent increases in rates. The city needs to relax the requirement for in-person application to allow for online registration. This is in line with the World Health Organization (WHO) lockdown rules to maintain social distancing and will also help to address the stigmatisation problem. Thus, the CoJ must consider accelerating the roll-out of broadband to townships as a way of facilitating access to internet and enhancing ESP online registrations. There is a need to increase the ESP poverty threshold of R6100 to cater for those on the border of poverty. Finally, the CoJ can increase people's access to food banks by diversifying its means in testing to include other criteria such as the Unemployment Insurance Fund (UIF), which will provide much needed relief to those that may have lost income.

\section{Conclusion}

The emergence of COVID-19 has paralysed the country's economic system, which consequently increases social evils of inequality and poverty. This article analysed the extent to which the existing CoJ ESP programme responds to COVID-19 food security challenges and consequently makes suggestions on how the programme can effectively address these food insecurity challenges. Key challenges affecting the effective implementation of the programme in the fight against COVID-19-induced food insecurity are lack of funding, lack of awareness to the programme objectives in all the regions of $\mathrm{CoJ}$, qualifying criteria, stigma and the shift from universal approach to a narrow target approach in disbursing ESP benefits, amongst others. Consequently, the indigent food banks do not address all the food insecurity challenges facing the citizens.

\section{Acknowledgements Competing interests}

The authors declare that they have no financial or personal relationships that may have inappropriately influenced them in writing this article. 


\section{Authors' contributions}

A.M., K.M., M.S.M., T.M. and T.M. contributed equally to this article.

\section{Ethical considerations}

This article followed all ethical standards for research without direct contact with human or animal subjects.

\section{Funding information}

This research received no specific grant from any funding agency in the public, commercial or not-for-profit sectors.

\section{Data availability}

The authors confirm that the data supporting the findings of this study are available within the article.

\section{Disclaimer}

The views and opinions expressed in this article are of the authors and do not necessarily reflect the official policy or position of any affiliated agency of the authors.

\section{References}

Babbie, E. \& Mouton, J., 2012, The practice of social research, Oxford University Press, Cape Town.

Bolongaro, I., 2020, Trudeau wins opposition backing for $\$ 57$ billion virus aid package, viewed 09 June 2020, from https://www.bloombergquint.com/ politics/trudeau-wins-opposition-backing-for-57-billion-canada-package.

Braun, V. \& Clarke, V., 2006, 'Using thematic analysis in psychology', Qualitative Research in Psychology 3, 77-101. https://doi.org/10.1191/1478088706qp063o

City of Johannesburg (CoJ), [2019]2020, Integrated development plan, Government Printers, Pretoria.

Cox, A., 2020, City of Joburg says it won't cut services of those unable to pay during lockdown, viewed 08 October 2020, from https://www.iol.co.za/the-star/news/ city-of-joburg-says-it-wont-cut-services-of-those-unable-to-pay-during lockdown-47712643.

Department of Agriculture, Forestry \& Fisheries (DAFF), 2013, National Policy on Food and Nutrition Security, Government Printers, Pretoria.

Doolan, D.M. \& Froelicher, E.S., 2009, 'Using an existing data set to answer new research questions: A methodological review', Research and Theory for Nursing Practice: An International Journal 23(3), 203-215. https://doi.org/10.1891/1541 6577.23.3.203

Ebrahim, T. \& Makwarela, M., 2018, City of Joburg's expanded social package offers little relief to residents of informal settlements, viewed 26 June 2020, from https://www.dailymaverick.co.za/article/2018-07-17-city-of-joburgs-expandedsocial-package-offers-little-relief-to-residents-of-informal-settlements/.

Expanded Social Package (ESP), 2018, Expanded social packages increases access to support poor residents, viewed 26 June 2020, from https://www.joburg.org.za/ media/Newsroom/Pages/2018\%20News\%20Articles/Extended-SocialPackages-\%E2\%80\%93-City-Increases-Access-to-Support-to-Poor-residents.aspx.

Food and Agriculture Organization, 1996, Rome declaration on world food security viewed 07 October 2020, from http://www.fao.org/3/w3613e/w3613e00.htm.
Fourie, C., 2018, All you need to know about Joburg's social benefits programme, the ESPJOBURG - Joburg's most vulnerable will get assistance through the Expanded Social Package (ESP), viewed 08 May 2020, from https://randburgsun.co. za/348749/need-know-joburgs-social-benefits-programme-esp/.

Gazette, 2020, Covid-19: City extends expanded social package rebates, viewed 07 May 2020, from https://rosebankkillarneygazette.co.za/283586/covid-19-cityextends-expanded-social-package-rebates/.

Gross, R., Pfeifer, H. \& Preuss, H.J., 2000, The four dimensions of food and nutrition security: Definitions and concepts, viewed 07 October 2020, from http://fpmu. gov.bd/agridrupal/sites/default/files/Four_Dimension_of_FS.pdf.

Growth and Development Strategy (GDS), 2019, A strategy for progressive change viewed 08 May 2020, from https://www.joburg.org.za/documents /Documents/ Joburg\%20GDS\%202040/Joburg\%202040\%20GDS_March\%202019.pdf.

Kumar, R., 2011, Research methodology: A step-by-step guide for beginners, 3rd edn., Sage, New Delhi.

Kyodo, J., 2020, 'Japan may dish out cash to households impacted by coronavirus', The Japan Times, viewed 26 June 2020, from https://www.japantimes.co.jp/ news/2020/03/26/business/economy-business/cash-benefits-coronavirus/\#. XoTNiohKg2w.

Maphanga, M. \& Mazenda, A., 2019, 'The effectiveness of the expanded public works programme as a poverty alleviation strategy', Administration Publica 27(3), 7-26.

Miles, M.B. \& Huberman, A.M., 1994, An expanded sourcebook: Qualitative data analysis, 2 nd edn., Sage, London.

Mtshali, B.P., 2018, The perception of the community of Diepkloof towards the expanded social package, University of Johannesburg, Johannesburg.

Parliamentary Monitoring Group, 2012, Food security policy and zero hunger programme: Progress report by Department of Agriculture, Forestry and Fisheries, viewed 26 June 2020, from http://pmg.org.za/committee-meeting/13903.

Ping, J.W., Cui, T. \& Pan, S.L., 2011, 'Strategies of crisis management from contingent perspective', in PACIS 2011 - 15th Pacific Asia conference on information systems: Quality research in Pacific, National University of Singapore, Queenstown, November 07.

Prasad, V. \& Jeffrey, S.F., 2020, 'Covid-19, a "supernova in human history" will need multiple perspectives to understand and manage', viewed 08 May 2020, from https://www.statnews.com/2020/05/14/underderstanding-covid-19-supernovahuman-history-multiple-perspectives.

Republic of South Africa, 1996, The Constitution of the Republic of South Africa, Government Printers, Pretoria.

Republic of South Africa, 1998, Skills Development Act (Act 97 of 1998), Government Printers, Pretoria.

Simone, G.A., 2018, Definitions of food security, the four dimensions of food security, food insecurity, food sovereignty and food systems, viewed 26 June 2020, from http://www.masterhdfs.org.

Socio-Economic Rights Institute of South Africa (SERI), 2018, Turning off the tap: Discontinuing universal access to free basic water in the City of Johannesburg, Working paper no. 3, SERI, Johannesburg.

South African Cities Network (SACN), [2018]2019, The state of the expanded public works programme in South African cities, Government Printers, Pretoria.

Wagner, C., Kawulich, B. \& Garner, M., 2012, Doing social research: A global context, McGraw-Hill Education, Berkshire.

Walker, P.G.T., Whittaker C., Watson O.J. \& Baguelin M., 2020, 'The impact of COVID-19 and strategies for mitigation and suppression in low- and middle-income countries', Science 369(6502): 413-422. https://doi.org/10.1126/science.abc0035

Webster, D., 2020, What happened to the Covid-19 special grant?, viewed 26 June 2020, from https://mg.co.za/coronavirus-essentials/2020-05-27-what-happenedto-the-covid-19-special-grant/.

Weible, C.M., Nohrstedt, D., Cairney, P., Carter, D.P., Crow, D.A., Durnová, A.P. et al, 2020, 'COVID-19 and the policy sciences: Initial reactions and perspectives', Policy Sciences 53, 225-241. https://doi.org/10.1007/s11077-020-09381-4

Werner, E, Stein, J. \& De Bonis, M., 2020, 'Negotiations intensify on Capitol Hill over massive stimulus legislation as coronavirus fallout worsens', The Washington Post, viewed 26 June 2020, from https://www.washingtonpost.com/ business/2020/03/18/trump-coronavirus-economic-plan/.

Woodward, J., 1958, Management and technology, Her Majesty's Stationary Office, London. 